\title{
Infectious disease threats to amphibian conservation
}

\author{
A.A. Cunningham \\ Institute of Zoology, Zoological Society of London, Regent's Park, London NW1 4RY \\ E-mail: A.Cunningham@ioz.ac.uk
}

\begin{abstract}
The unexplained decline of amphibian populations across the world was first recognised in the late 20th century. When investigated, most of these "enigmatic" declines have been shown to be due to one of two types of infectious disease: ranavirosis caused by infection with FV3-like ranavirus or with common midwife toad virus, or chytridiomycosis caused by infection with Batrachochytrium dendrobatidis or B. salamandrivorans. In all cases examined, infection has been via the humanmediated introduction of the pathogen to a species or population in which it has not naturally coevolved. While ranaviruses and B. salamandrivorans have caused regionally localised amphibian population declines in Europe, the chytrid fungus, $B$. dendrobatidis, has caused catastrophic multi-species amphibian population declines and species extinctions globally. These diseases have already caused the loss of amphibian biodiversity, and over $40 \%$ of known amphibian species are threatened with extinction. If this biodiversity loss is to be halted, it is imperative that regulations are put in place - and enforced - to prevent the spread of known and yet-to-be discovered amphibian pathogens. Also, it is incumbent on those who keep or study amphibians to take measures to minimise the risk of disease spread, including from captive animals to those in the wild.
\end{abstract}

\section{INTRODUCTION}

When the first World Congress of Herpetology was held in Canterbury, Kent in 1989, no papers were presented about the amphibian conservation crisis. It was only during social interactions at coffee and tea breaks and in the evenings that many herpetologists from around the world realised that it was not only their own study species that appeared to be undergoing declines or even local disappearances, but also those being studied by many of their colleagues. Whilst "localised" declines were initially thought to be due to natural population cycles or local, short-term factors such as extreme weather events, it soon became clear that there was a larger issue affecting amphibians and a call for action was made.

In response, the International Union for the Conservation of Nature (IUCN) set up the Declining
Amphibian Populations Task Force (DAPTF) to investigate if the reported declines of amphibians was a true phenomenon and, if so, what was, or were, the cause(s) of it. The DAPTF brought together experts from across the world and from across disciplines to promote research into amphibian declines and to collate and evaluate evidence that showed amphibians were undergoing unprecedented declines around the world including in protected areas and in pristine habitats. Indeed, it is now known that $41 \%$ of known amphibian species are threatened with extinction, which is a much higher percentage than for mammals (25\%) and over three times the percentage for birds (13\%) (IUCN, 2018). Perhaps just as worrying is that over $61 \%$ of known amphibian species are either "Not Evaluated" or have out-of-date assessments; this compares to just $0.2 \%$ of mammals and $0 \%$ of birds (Tapley et al., 2018).

Initially, habitat destruction, overexploitation, excessive UV-B irradiation, pesticide use, acid rain and other pollutants were all put forward as likely causes of the amphibian decline phenomenon. Through the work of the DAPTF's Diseases and Pathology Working Group, however, infectious disease - and one in particular, chytridiomycosis due to infection with the non-hyphal, zoosporic fungus, $B$. dendrobatidis - was identified as elevating amphibian mortality rates and driving amphibian population declines across multiple continents (Cunningham, 1998). This fungus was discovered contemporaneously as the cause of multi-species mortality of wild amphibians where frog populations were declining catastrophically in the rain forests of Panama and Australia (Berger et al., 1998) and was named following its isolation from a captive blue poison dart frog (Dendrobates azureus) (Longcore et al., 1999).

While previously dismissed as being irrelevant to species demographics, in recent decades infectious disease has been increasingly identified as a driver of species declines and extinctions (Daszak et al., 2000; Cunningham et al., 2017). For amphibians, in particular, there is now substantial and irrefutable evidence of the role of infectious disease in multiple species declines and in some species extinctions (e.g. Schloegel et al., 2006; Skerratt et al., 2007). The 
presence of disease, however, should not always be seen as a negative thing. Disease-causing agents, such as pathogens, are important components of ecosystems, often crucial for the regulation of species abundances and for ecosystem function; for example, the experimental removal of fungal pathogens from rain forest plants has been shown to adversely affect biodiversity through the reduction of species richness (Bagchi et al., 2014). When infectious disease threatens species conservation it is inevitably a consequence of human-mediated factors that have decreased the resilience of a species to a pre-existing pathogen, or that have introduced a "novel" pathogen to a naïve species (Cunningham et al., 2003).

When pathogens are in the "wrong" place (i.e. in species or locations in which they did not co-evolve), their presence can lead to adverse effects on biodiversity and ecosystem function (Cunningham 1996; Daszak et al., 2000; Cunningham et al., 2017). This usually is consequent to human-mediated introduction: a process which has been termed "pathogen pollution" (Cunningham et al., 2003). The introduction of pathogens can have long-term, profound and unpredictable impacts on nature. One example of this is the introduction of myxomatosis to the rabbit (Oryctolagus cuniculus) population in the United Kingdom (U.K). Who could have predicted that, through complex interactions between rabbits, grasses, wild thyme (Thymus polytrichus), and a red ant (Myrmica sabuleti), that the introduction of a rabbit virus would, over a course of 30 years, lead to the extinction of the large blue butterfly (Maculinea arion) in the U.K. (Sumption \& Flowerdew, 1985)?

Until recently, amphibians were very much the "Cinderella" of the wildlife disease world, with very little attention being given to identifying, understanding or mitigating the causes of amphibian morbidity or mortality. Many advances in this field have been made in the past 30 years or so. However, although many infectious diseases of amphibians are now recognised - and there are undoubtedly many more waiting to be discovered - only two have been shown to cause amphibian population declines in wild populations: ranavirosis and chytridiomycosis. The key points about these diseases, with particular reference to the situation in the U.K., will now be reviewed.

\section{AMPHIBIAN RANAVIROSIS}

Amphibian ranavirosis is caused by infection with any one of a large number of different types of virus in the genus Ranavirus (known as ranaviruses) that can infect amphibians. First identified as a cause of amphibian mortality in the 1960s when the mortality of North American bullfrog (Lithobates catesbeianus - formerly Rana catesbeiana) tadpoles was investigated (Wolf et al., 1968), over recent years there has been a large increase in the number of ranaviruses, and ranavirus-related mortality incidents, described globally (Duffus et al., 2015). Of these, only two have been shown to cause long-term amphibian population declines: a frog virus 3-like ranavirus in the U.K (Teacher et al., 2010) and common midwife toad virus (CMTV) in Spain (Price et al., 2014). Ranavirus-associated amphibian mortality was first detected in the U.K. in the early 1990s, although it had probably been occurring for some years before this (Drury et al., 1995; Cunningham et al., 1996). Large disease outbreaks involving the deaths of tens or hundreds of animals, usually the common frog (Rana temporaria), but also the common toad (Bufo bufo), were reported (Cunningham et al., 1996; Cunningham et al., 2007). In most cases, outbreaks affected adult animals, occurred in the summer months and were peracute (i.e. very short period from first signs of illness to death), with a large number of dead animals being found in the vicinity of a breeding pond over a short period of time (hours or days) (Fig. 1). In the U.K, two types of disease (or syndrome) have been described due to ranavirus infection: haemorrhagic syndrome and skin-ulceration syndrome (Cunningham et al., 1996; Cunningham, 2001). With haemorrhagic syndrome, affected animals - although dead - usually appear normal from the outside, although bleeding might be seen from the mouth or vent and the skin can appear reddened, especially on the underside of the hind legs and body. On post mortem examination, animals are often in good body condition but with evidence of bleeding throughout most of the body systems, including into the gastro-intestinal tract, reproductive tract, skeletal musculature, and even into the fat bodies (stores). These animals are killed very quickly by the virus; usually within a matter of hours after the first onset of illness. Animals which develop skin-ulceration syndrome, however, can be ill for weeks or even months before they die. These animals develop skin ulceration, which can be extensive and which can occur over any part of the body but is most frequently seen over the ventral hind legs (Fig. 2). Affected animals can also undergo necrosis (death) of the limbs. While, if present, this usually affects the hind and fore feet, it can extend higher up the limbs to reach the body. During the period of illness, animals stop feeding and become listless and lethargic. By the time they die they are usually in very poor body condition and sometimes are emaciated. There is, however, some evidence that a small proportion of common frogs affected with skin-ulceration syndrome might recover as apparently-healthy animals have been found a year after an outbreak with scarring indicative of healed skin ulcers (Cunningham, 2001).

Molecular characterisation of the FV3-like virus causing mortality in British frogs showed the virus to be indistinguishable from FV3-like ranaviruses in the U.S.A., and to be distinct from those infecting amphibians or fish elsewhere, including in continental Europe (Hyatt et al., 2000). It has, therefore, been suggested that the virus is a recent 


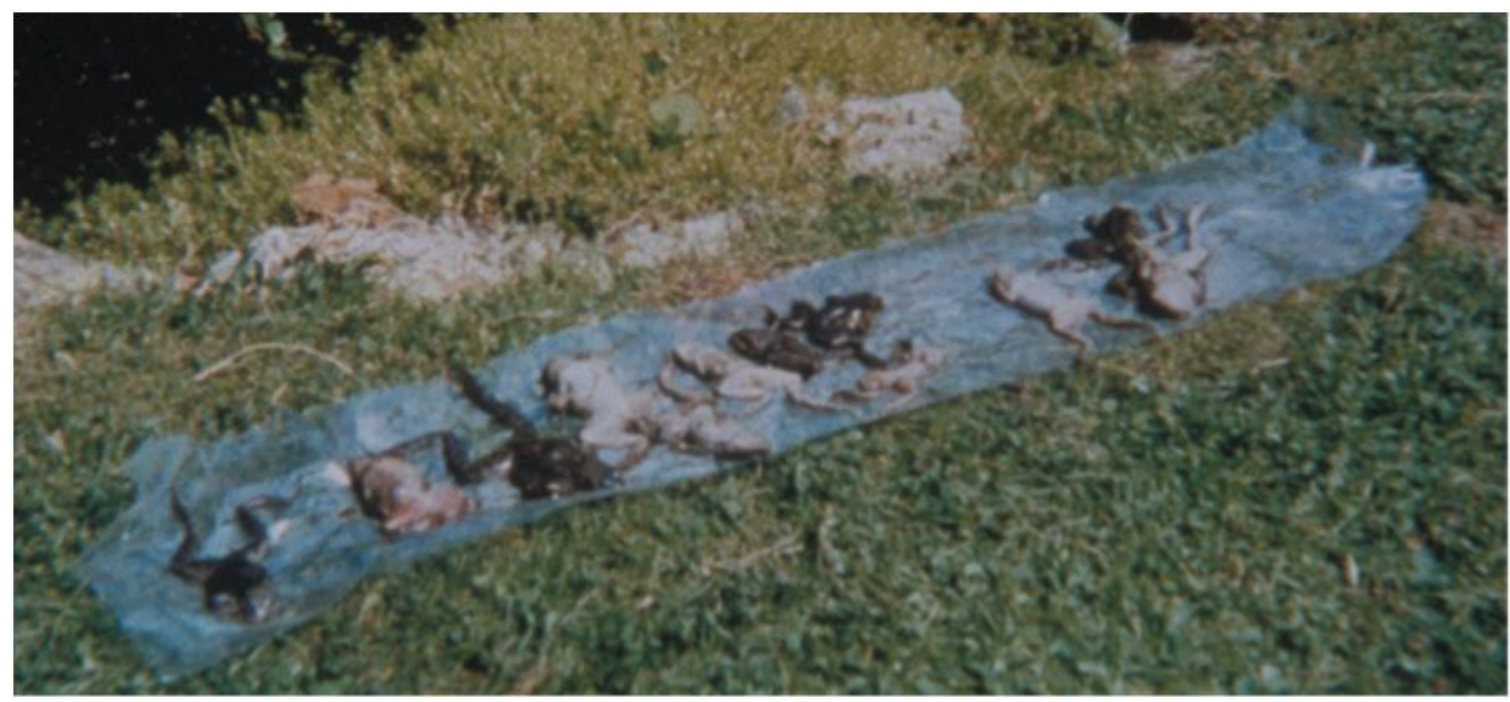

Fig. 1. Mass mortality of common frogs (Rana temporaria) in the U.K. due to ranavirus infection. Affected animals in such mass mortality events exhibit systemic haemorrhagic disease (see text). (Photo: Frog Mortality Project)

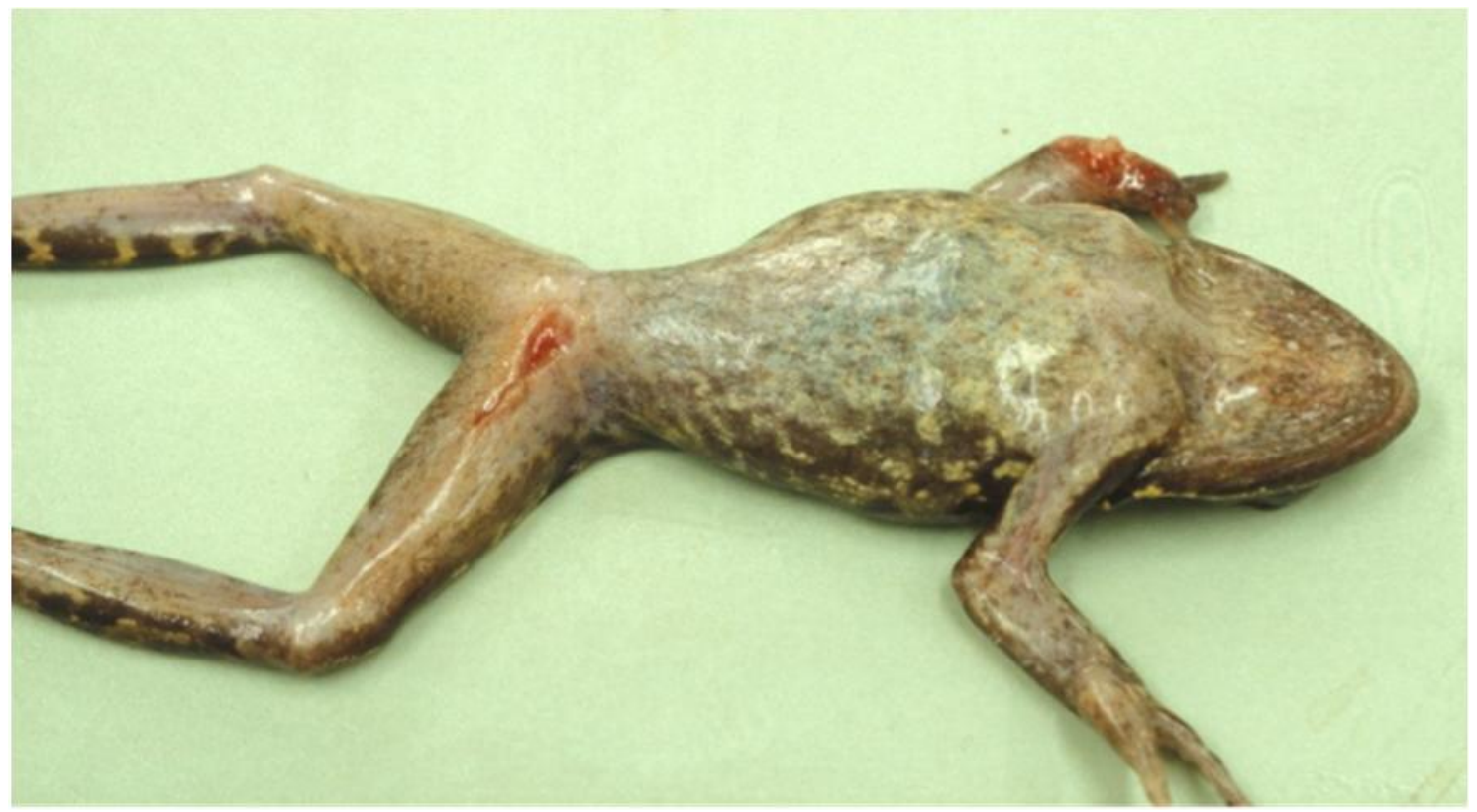

Fig. 2. A dead common frog (Rana temporaria) with lesions typical of the skin ulceration form of ranavirosis. Note the long, thin (linear) ulcer on the animal's left ventral thigh and the loss of digits on the right forefoot along with part of that foot. (Photo: Zoological Society of London)

incursion into the U.K., possibly along with North American bullfrogs, which were imported into the U.K. by the pet trade in the 1980s: this species is known to be a carrier of FV3-like ranaviruses (Cunningham, 2001).

Teacher et al. (2010) compared frog populations at 18 ranavirus-positive sites with recurring frog mortality with those at 16 ranavirus-negative sites where no unusual mortality events had been reported. Over the period 1996 to 2008, there was no overall change in population size at the ranavirusnegative sites, but at the ranavirus-positive sites there was an overall decline in the frog populations of $83 \%$. It is clear, therefore, that in addition to causing one-off mass-mortality events, ranavirus can lead to long-term population declines of the common frog in the U.K.

The ranavirus, CMTV, was first described as a cause of systemic haemorrhagic disease causing high mortality in tadpoles of the common midwife toad (Alytes obstetricans) in the Picos de Europa National Park in northern Spain (Balseiro et al., 2009). Subsequent to the initial disease outbreak, CMTV, which is in a sister clade to FV3-like ranaviruses, caused recurring multi-year disease outbreaks in multi-species amphibian assemblages in the National Park, leading to long-term, severe population declines with no evidence of recovery over at least a five-year period (Price et al., 2014). 


\section{AMPHIBIAN CHYTRIDIOMYCOSIS}

Amphibian chytridiomycosis is the name given to disease in an amphibian caused by infection with a chytrid fungus. To date only two such fungal pathogens of amphibians are known: Batrachochytrium dendrobatidis and $B$. salamandrivorans. $B$. dendrobatidis specifically infects keratinised cells; these cells form the outer surface of the skin of metamorphosed amphibians and the mouthparts of some anuran larvae. While infection of the latter can cause loss of mouthparts and possible delayed development of larvae, generally it is infection of metamorphosed animals that causes mortality. Ironically, infected larvae can survive to metamorphose, only to then develop a skin infection and die, usually within 2 - 3 weeks of metamorphosis. As $B$. dendrobatidis is an intracellular pathogen, meaning that it invades, lives and grows within amphibian cells, the infection fails to elicit a noticeable inflammatory cell response yet interferes with normal skin function, in particular with osmoregulation (the skin's ability to regulate electrolytes within the body) (Voyles et al., 2010). This leads to ion imbalances, one of the most dangerous of which is a decrease in the concentration of potassium ions in the blood. Reduced potassium levels lead to abnormal electrical activity in the heart, with eventual cardiac arrest (Voyles et al., 2009). B. salamandrivorans also infects amphibian skin, often causing skin ulceration, but how it kills its host is currently unknown (Martel et al., 2013).

B. dendrobatidis was discovered in the 1990s consequent to the DAPTF Diseases and Pathology Working Group disseminating the latest results and then bringing researchers and their findings together from across the world (Berger et al., 1998; Cunningham, 1998; Longcore et al., 1999). This was the first time a cause of unexplained amphibian declines had been described and, although at the time many herpetologists were sceptical that an infectious disease could be the cause, the weight of subsequent research has dismissed any such doubt. For example, a close association has been shown between the passage of a north-to-south wave of amphibian declines through Central America and a (retrospectively determined) contemporaneous wave of first identification of $B$. dendrobatidis in amphibians collected across the region (Lips et al., 2006). The introduction of the pathogen to the Caribbean islands of Dominica (in 2002) and Montserrat (in 2009) led to the rapid and almost complete extirpation of the mountain chicken frog (Leptodactylus fallax) due to chytridiomycosis (Hudson et al., 2016) (Fig. 3). In Montserrat, the absence of $B$. dendrobatidis had been established in the early 2000s (Garcia et al., 2007), so its emergence on the island must have been a result of pathogen introduction, and this was almost certainly the case also in Dominica (Hudson et al., 2016). There is compelling evidence that $B$. dendrobatidis infection is

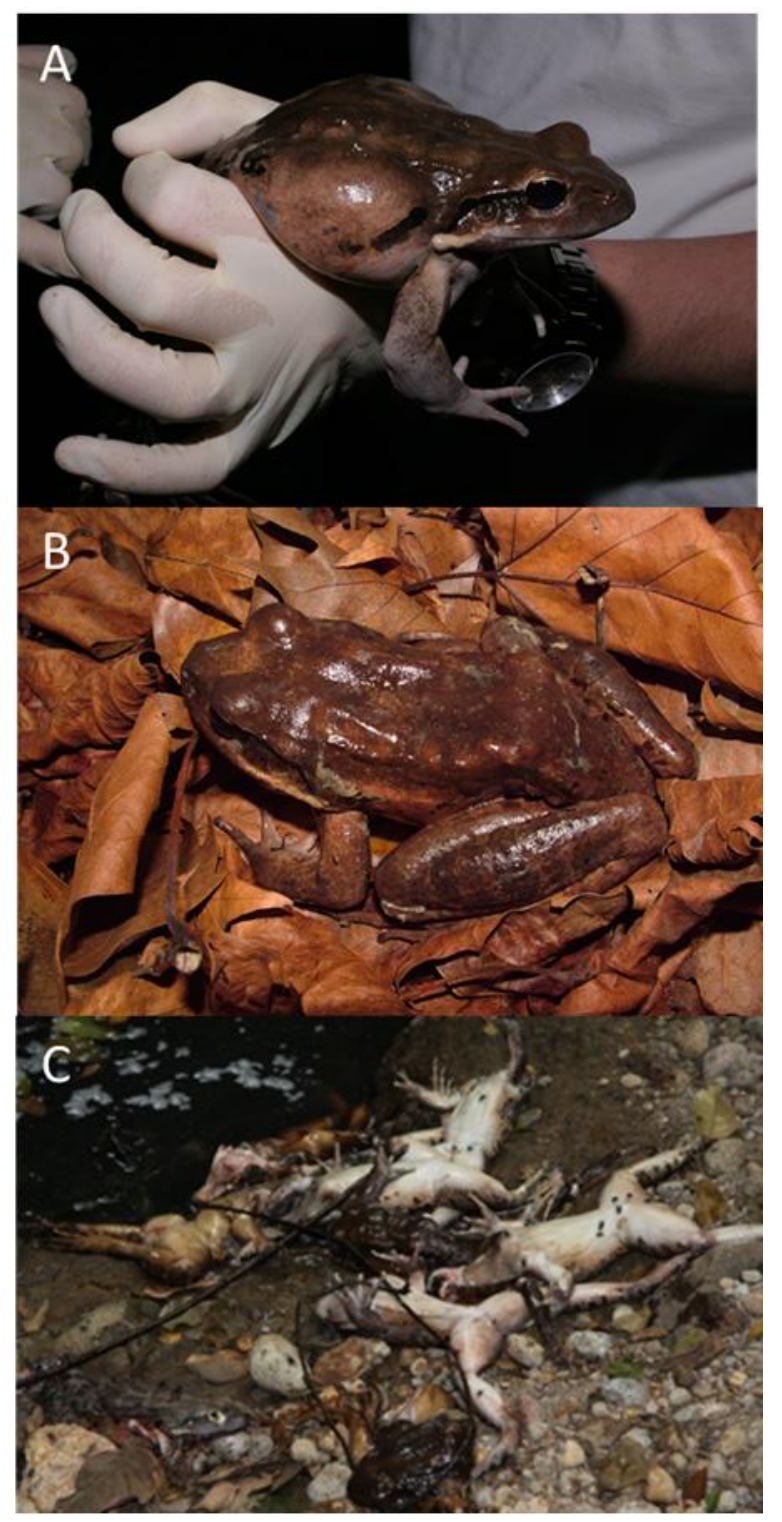

Fig. 3. Mountain chicken frog (Leptodactylus fallax). (A) A healthy individual in Dominica. (B) An individual with chytridiomycosis due to Batrachochytrium dendrobatidis infection. (C) Dead individuals in Dominica killed by chytridiomycosis. (Photos: Zoological Society of London and A. James)

a driver of southern Darwin's frog (Rhinoderma darwinii) declines in Chile, South America (Soto-Azat et al., 2013; Valenzuela-Sánchez et al., 2017), where it is also an introduced pathogen (ValenzuelaSánchez et al., 2018; O'Hanlon et al., 2018). Indeed, infection with $B$. dendrobatidis has now been identified as a cause of amphibian mortality and population decline on every continent where amphibians exist. In the U.K., the pathogen has been commonly found in captive amphibians in which it sometimes has been found to be a cause of mortality, whilst nationwide surveys of $B$. dendrobatidis have shown wild amphibians to be infected with the pathogen at multiple sites across mainland Great Britain, but without obvious signs of disease (author's unpublished observations). Further studies involving long-term population monitoring 
and infection surveillance are required to determine if native British amphibians are unaffected by $B$. dendrobatidis infection, or if the pathogen is causing the long-term decline of any species in the same, cryptic, way that it is doing so with the southern Darwin's frog in Chile.

As research into $B$. dendrobatidis has progressed, it has become apparent that there are multiple lineages of the fungus, of which infection with one - termed the global pandemic lineage (BdGPL) - is responsible for almost all known cases of amphibian population decline due to chytridiomycosis resulting from infection with $B$. dendrobatidis. The natural area of endemicity of $B$. dendrobatidis, appears to be South East Asia; more specifically, the Korean peninsula (O'Hanlon et al., 2018). Movement of the pathogen from this geographical location probably occurred inadvertently with the growth in the international trade of amphibians. It has been hypothesised that this led to different lineages of $B$. dendrobatidis coming into contact with each other, probably through the co-infection of amphibians, and hybridising to form BdGPL (Farrer et al., 2011). Indeed, Farrer et al. (2011) used molecular clock analyses to date the emergence of BdGPL to around the time of the emergence of the global amphibian trade. Using data from a much larger number of isolates of $B$. dendrobatidis collected from around the world, O'Hanlon et al. (2018) have since verified these results, concluding that BdGPL emerged during the early 20th century, when the long-distance international trade in amphibians was becoming established. It is likely that, subsequent to the emergence of BdGPL, it was spread globally via the international amphibian trade, which is now huge in both monetary and volume terms, and which is largely unregulated and unrecorded (e.g. Schloegel et al., 2010; Peel et al., 2012; Wombwell et al., 2016). While thought to be a hybrid itself, there is recent evidence that BdGPL is hybridising with other $B$. dendrobatidis lineages (e.g. in Brazil and in South Africa) and, where it is doing so, the hybrid lineage is even more virulent to amphibians than BdGPL (Greenspan et al., 2018; O'Hanlon et al., 2018). Thus, even if a country or geographical region is known to be positive for $B$. dendrobatidis, it is important to prevent the movement and mixing of lineages as this could facilitate even more catastrophic amphibian population declines through the creation and spread of hybrids.

B. salamandrivorans was discovered in 2013, when it was identified as the cause of fire salamander (Salamandra salamandra) mortality, with subsequent population extirpation, in the Bunderbos forest on the Netherlands-Belgium border (Martel et al., 2013). It has since spread to Belgium and western Germany, where it is also causing localised extinctions of the fire salamander and possibly also other species of urodele (Spitzen-van der Sluijs et al., 2016). Unlike B. dendrobatidis, which has been shown to infect and kill species in all three orders of the Amphibia (Anura, Urodela and Gymnophiona) (Doherty-Bone et al., 2013; Gower et al., 2013), to date $B$. salamandrivorans is known only to kill urodeles (newts and salamanders) - although it is known to be able to infect at least some members of the Anura, hence they might also be able to act as vectors of the pathogen (Martel et al., 2014; Stegen et al., 2017). As with B. dendrobatidis, in the locations where it is causing amphibian mortality and declines, $B$. salamandrivorans is an introduced pathogen; its area of natural endemicity is south east Asia (Laking et al., 2017; Martel et al., 2014) and it is most likely to have been introduced into Europe via the amphibian pet trade (Martel et al., 2014; Nguyen et al., 2017; Yuan et al., 2018).

Despite extensive surveillance, $B$. salamandrivorans infection has not yet been found in any wild amphibian in the U.K. (author's unpublished observations), but the infection has been found to be widespread in captive collections in Great Britain and elsewhere in Western Europe (Fitzpatrick et al., 2018; Sabino-Pinto et al., 2018) (Fig. 4). At least one native British amphibian, the great crested newt (Triturus cristatus), is known to be highly susceptible to lethal infection with $B$. salamandrivorans (Martel et al., 2014), therefore measures should be taken to prevent the spread of this pathogen into wild amphibian populations.

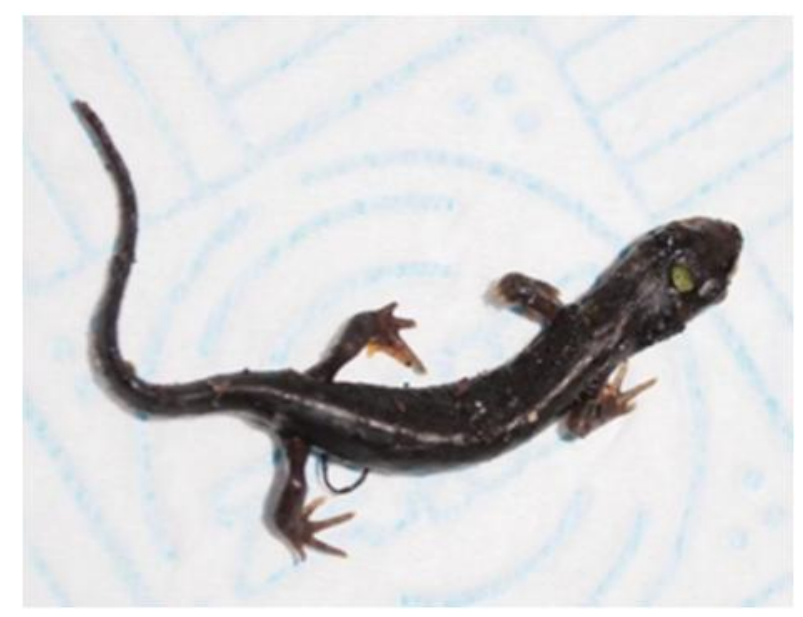

Fig. 4. A captive Bosca's newt (Lissotriton boscai) in the U.K. with chytridiomycosis due to Batrachochytrium salamandrivorans infection. Note the emaciated body condition and lack of grossly visible skin lesions. (Photo: $\mathrm{L}$. Fitzpatrick)

\section{CONCLUSIONS AND RECOMMENDATIONS}

Since the mid-1990s, there has been a growing body of evidence that infectious diseases caused by chytrid fungi and ranaviruses have been causing unprecedented rates of mortality and population declines of amphibians. While ranaviruses and $B$. salamandrivorans have caused regionally localised amphibian population declines in Europe, $B$. dendrobatidis has caused catastrophic multi-species amphibian population declines and species 
extinctions globally (e.g. Skerratt et al., 2007). The identification of different lineages of $B$. dendrobatidis, including the emergence of multiple hyper-virulent hybrids (including BdGPL, which is thought to have emerged in the early 20th century) resulting from the human-mediated movement of these fungi around the world, is of particular concern. Thus, even if populations of wild amphibians appear to be stable while infected with $B$. dendrobatidis, an incursion of a different lineage (or hybrid) could result in declines due to chytridiomycosis. Also, the occurrence of a stable host-pathogen system - as appears to be the case in the U.K. - could be deceptive, as has been shown for the southern Darwin's frog in Chile (ValenzuelaSanchez et al., 2017).

In order to protect amphibian populations and diversity, therefore, it is important that steps are taken to prevent the national or international spread of amphibian pathogens, and particularly their incursion into the wild. Both $B$. dendrobatidis and ranaviruses were listed by the World Organisation for Animal Health (OIE), meaning that, under World Trade Organisation agreements, governments are allowed to put measures in place to prevent the intentional or unintentional import of these pathogens into their countries (Schloegel et al., 2010). This was the first time that any pathogen had been listed on the grounds of biodiversity protection; previously all pathogens were listed to protect livestock or public health. Despite this listing, no government has actually enacted or enforced protection measures against these amphibian pathogens.

More recently, the European Commission has implemented controls to prevent the spread of $B$. salamandrivorans within the European Union (EU). Measures include the requirement for amphibians to be quarantined and to test negative (using a pathogen-specific qPCR; Blooi et al., 2013) for $B$. salamandrivorans infection before entry to the EU or before being traded across national borders within the EU (European Commission, 2018). At the time of writing, however, in the U.K. (and most probably elsewhere in the EU), there are no official quarantine facilities, testing laboratories or methods of certification that animals are free of infection. Also, there are no measures in place for the enforcement of these controls.

Public pressure is required in order to encourage politicians and other policy makers to take infectious disease threats to amphibian conservation seriously and to bring in, and enforce, regulations to minimise the spread and impact of these diseases. There are, however, a number of steps that herpetologists, ecology consultants and others can take to minimise their role in the introduction and spread of diseases to new locations or amphibian populations. These include taking simple biosecurity measures to prevent infections from spreading from captive amphibians to those in the wild and measures to minimise the chances of spreading diseases from one wild population to another.

Steps to prevent the spread of infectious diseases from captive to wild animals are summarised in Table 1. These are detailed in a leaflet which has been distributed by the pet trade, herpetological and conservation non-governmental organisations, and the government which is available from https://www.ornamentalfish.org/wp-

content/uploads/2015/07/Amphibian-disease-

alert_June-20151.pdf

Steps to prevent the spread of infectious diseases between different wild amphibian populations are detailed in the Amphibian and Reptile Groups' Advice Note 4: Amphibian Disease Precautions: A Guide for UK Fieldworkers, which is available at www.arguk.org/ Additional information about biosecurity procedures when visiting amphibian habitats is available on the "BsalEurope" web site http://bsaleurope.com/hygiene-protocols/

It is up to us all - whether we work with amphibians on a professional basis, keep them as pets or as a hobby, or just appreciate their existence - to do whatever we can to halt the rising tide of amphibian extinctions, so long as those actions are based on evidence and sound science. Actions, such as disinfecting equipment between enclosures or disinfecting footwear between amphibian habitats in the wild, might appear small but they all play important and significant roles in reducing disease spread and pressure on amphibian populations.

\section{ACKNOWLEDGEMENTS}

I am grateful to Arlington James for providing Fig. 3C and to Liam Fitzpatrick for providing Fig. 4. 
Table 1. Biosecurity measures that should be taken to minimise the chances of infectious disease spread from captive to wild amphibians.

\begin{tabular}{|c|c|}
\hline Source of Disease Threat & Biosecurity Measures \\
\hline Captive amphibian trade & $\begin{array}{l}\text { - Ideally, only obtain amphibians that have tested negative for } \\
\text { chytrid fungi. } \\
\text { - Even if the infection status of the new animals is known, always } \\
\text { quarantine new arrivals and screen for chytrid infections on } \\
\text { arrival. } \\
\text { - Any positive animals should be treated under veterinary } \\
\text { supervision and test negative before being added to your } \\
\text { collection. }\end{array}$ \\
\hline Keeping captive amphibians & $\begin{array}{l}\text { Do not assume that a healthy looking animal is free of infection; } \\
\text { some animals can act as carriers without exhibiting signs of } \\
\text { disease. } \\
\text { - Adopt the precautionary principle and manage all amphibians as } \\
\text { if they are infected. } \\
\text { Know the health status of your collection. Get your animals } \\
\text { tested for chytrid fungi and ensure any dead amphibians are } \\
\text { submitted for post mortem examination, including testing for } \\
\text { chytrid fungi and ranaviruses. }\end{array}$ \\
\hline $\begin{array}{l}\text { Maintenance procedures for } \\
\text { amphibians in captivity }\end{array}$ & $\begin{array}{l}\text { Do not clean tanks or vivaria outside where there is a possibility } \\
\text { of contaminating areas used by wild animals. } \\
\text { - To avoid spreading disease within a collection, disinfect } \\
\text { equipment between enclosures or have dedicated equipment for } \\
\text { each enclosure. } \\
\text { - Equipment and furnishings should be regularly cleaned and } \\
\text { disinfected. } \\
\text { - Disinfect all waste water from amphibian enclosures. Bleach, } \\
\text { Virkon, F10 and Anigene are some disinfectants that will kill the } \\
\text { majority of amphibian pathogens provided the manufacturers' } \\
\text { guidelines are followed. } \\
\text { - All waste water, once disinfected, should be discharged down a } \\
\text { drain connected to a sewer. } \\
\text { Substrates (soil, sand, gravel, etc.) can harbour infections and } \\
\text { should be discarded carefully. Ideally these should be sent for } \\
\text { incineration by a registered company that can dispose of clinical } \\
\text { waste (e.g. those used by veterinary practices). If this is not } \\
\text { possible, disinfect and then dispose with the household refuse for } \\
\text { collection by your local authority. }\end{array}$ \\
\hline Enclosures & $\begin{array}{l}\text { Avoid keeping amphibians in outdoor enclosures as they may } \\
\text { come into direct or indirect contact with native wild amphibians } \\
\text { and infect them with disease agents (even if the captive animals } \\
\text { appear healthy). }\end{array}$ \\
\hline Contact with wild amphibians & $\begin{array}{l}\text { - Never share equipment, such as nets, between amphibians in } \\
\text { captivity and those in the wild. } \\
\text { - Never release any (native or exotic) amphibians from captivity } \\
\text { into the wild. (This includes releasing into a garden pond, as this } \\
\text { will also enable any pathogens present to get into the wild.) }\end{array}$ \\
\hline
\end{tabular}




\section{REFERENCES}

Bagchi, R., Gallery, R.E., Gripenberg, S., Gurr, S.J., Narayan, L., Addis, C.E. et al. (2014). Pathogens and insect herbivores drive rainforest plant diversity and composition. Nature 506, 85-88.

Balseiro, A., Dalton, K.P., del Cerro, A., Marquez, I., Cunningham, A.A., Parra, F., et al. (2009). Pathology, isolation and molecular characterization of a ranavirus from the common midwife toad (Alytes obstetricans) on the Iberian Peninsula. Diseases of Aquatic Organisms 84, 95104.

Berger, L., Speare, R., Daszak, P., Greene, D.E., Cunningham, A.A., Goggin, C.L. et al. (1998). Chytridiomycosis causes amphibian mortality associated with population declines in the rain forests of Australia and Central America. Proceedings of the National Academy of Sciences of the U.S.A. 95, 9031-9036.

Blooi, M., Pasmans, F., Longcore, J.E., Spitzen-van der Sluijs, A., Vercammen, F. \& Martel, A. (2013). Duplex real-time PCR for rapid simultaneous detection of Batrachochytrium dendrobatidis and Batrachochytrium salamandrivorans in amphibian samples. Journal of Clinical Microbiology 51, 4173-4177.

Cunningham, A.A. (1996). Disease risks of wildlife translocations. Conservation Biology 10, 349-353.

Cunningham, A.A. (2001). Investigations into Mass Mortalities of the Common Frog (Rana temporaria) in Britain: Epidemiology and Aetiology. Ph.D. Thesis, University of London.

Cunningham, A.A., Langton, T.E.S., Bennett, P.M., Lewin, J.F., Drury, S.E.N., Gough, R.E. et al. (1996). Pathological and microbiological findings from incidents of unusual mortality of the common frog (Rana temporaria). Philosophical Transactions of the Royal Society B 351, 15391557.

Cunningham, A.A. (1998). A breakthrough in the hunt for a cause of amphibian declines. Froglog Newsletter of the Declining Amphibian Populations Task Force 30, 3-4.

Cunningham, A.A., Daszak, P. \& Rodríguez, J.P. (2003). Pathogen pollution: defining a parasitological threat to biodiversity conservation. Journal of Parasitology 89, S78-S83.

Cunningham, A.A., Hyatt, A.D., Russell, P. \& Bennett, P.M. (2007). Experimental transmission of a ranavirus disease of common toads (Bufo bufo) to common frogs (Rana temporaria). Epidemiology and Infection 135, 1213-1216.

Cunningham, A.A., Daszak, P. \& Wood, J.L.N. (2017). One health, emerging infectious diseases, and wildlife: two decades of progress? Philosophical Transactions of the Royal Society B 372, 20160167. doi.org/10.1098/rstb.2016.0167

Daszak, P., Cunningham, A.A. \& Hyatt, A.D. (2000). Emerging infectious diseases of wildlife: threats to biodiversity and human health. Science 287, 443-449.
Doherty-Bone, T.M., Gonwouo, N.L., Hirschfeld, M., Ohst, T., Weldon, C., Perkins, M. et al. (2013). Batrachochytrium dendrobatidis in amphibians of Cameroon, including first records of infected caecilian hosts. Diseases of Aquatic Organisms 102, 187-194.

Drury, S.E.N., Gough, R.E. \& Cunningham, A.A. (1995). Isolation of an Iridovirus-like agent from common frogs (Rana temporaria). Veterinary Record 137, 72-73.

Duffus, A.L.J., Waltzek, T.B., Stöhr, A. C., Allender, M.C., Gotesman, M., Whittington, et al. (2015). Distribution and host range of ranaviruses. In: Gray, M., Chinchar, V. (Editors). Ranaviruses: Lethal Pathogens of Ectothermic Vertebrates. Springer, Heidelberg, Germany. https://link.springer.com/book/10.1007/978-3-319-13755-1

European Commission (2018). Commission Implementing Decision (EU) 2018/320 of 28 February 2018 on certain animal health protection measures for intra-Union trade in salamanders and the introduction into the Union of such animals in relation to the fungus Batrachochytrium salamandrivorans (notified under document C(2018) 1208)

http://eur-lex.europa.eu/eli/dec_impl/2018/320/oj

Farrer, R.A., Weinert, L.A., Bielby, J., Garner, T.W.J., Balloux, F., Clare, F. et al. (2011). Multiple emergences of amphibian chytridiomycosis include a globalised hypervirulent recombinant lineage. Proceedings of the National Academy of Sciences of the U.S.A. 108, 18732-18736.

Fitzpatrick, L., Pasmans, F., Martel, A. \& Cunningham, A.A. (2018). Epidemiological tracing of Batrachochytrium salamandrivorans in private amphibian collections identifies widespread infection and associated mortalities in Western Europe. Scientific Reports 8, 13845.

Garcia, G., Cunningham, A.A., Horton, D.L., Garner, T.W.J., Hyatt, A., Hengstberger, S. et al. (2007). Mountain chickens Leptodactylus fallax and sympatric amphibians appear to be disease free on Montserrat. Oryx 41, 398-401.

Gower, D.J., Doherty-Bone, T., Loader, S.P., Wilkinson, M., Kouete, M.T., Tapley, B. et al. (2013). Batrachochytrium dendrobatidis infection and lethal chytridiomycosis in caecilian amphibians (Gymnophiona). EcoHealth 10, 173-183.

Greenspan, S.E., Lambertini, C., Carvalho, T., James, T.Y., Toledo, L.F., Haddad, C.F.B. et al. (2018). Hybrids of amphibian chytrid show high virulence in native hosts. Scientific Reports 8, 9600.

Hudson, M.A., Young, R.P., D’Urban Jackson, J., Orozco-terWengel, P., Martin, L., James, A. et al. (2016). Dynamics and genetics of a diseasedriven species decline to near extinction: lessons for conservation. Scientific Reports 6, 30772.

Hyatt, A.D., Gould, A. R., Zupanovic, Z., Cunningham, A.A., Hengstberger, S., Whittington, R.J. et al. (2000). Characterisation of piscine and 
amphibian iridoviruses. Archives of Virology 145, 301-331.

IUCN (2018). Red List of Threatened Species. Version 2018-1. www.iucnredlist.org

Laking, A.E., Ngo, H.N., Pasmans, F., Martel, A. \& Nguyen, T.H. (2017). Batrachochytrium salamandrivorans is the predominant chytrid fungus in Vietnamese salamanders. Scientific Reports 7, 44443.

Lips, K.R., Brem, F., Brenes, R., Reeve, J.D., Alford, R.A., Voyles, J. et al. (2006). Emerging infectious disease and the loss of biodiversity in a Neotropical amphibian community. Proceedings of the National Academy of Sciences of the U.S.A. 103, 3165-3170.

Longcore, J.E., Pessier, A. P. \& Nichols, D.K. (1999). Batrachochytrium dendrobatidis gen. et sp. nov., a chytrid pathogenic to amphibians. Mycologia 91, 219-227.

Martel, A., Blooi, M., Adriaensen, C., Van Rooij, P., Beukema, W., Fisher, M.C. et al. (2014). Recent introduction of a chytrid fungus endangers Western Palearctic salamanders. Science 346, 630-631.

Martel, A., Spitzen-van der Sluijs, A., Blooi, M., Bert, W., Ducatelle, R., Fisher, M.C. et al. (2013). Batrachochytrium salamandrivorans sp. nov. causes lethal chytridiomycosis in amphibians. Proceedings of the National Academy of Sciences of the U.S.A. 110, 15325-15329.

Nguyen, T.T., Nguyen, T. V., Ziegler, T., Pasmans, F. \& Martel, A. (2017). Trade in wild anurans vectors the urodelan pathogen Batrachochytrium salamandrivorans into Europe. Amphibia-Reptilia 38, 554-556.

Peel, A.J., Hartley, M. \& Cunningham, A.A. (2012). Qualitative risk analysis for the importation of Batrachochytrium dendrobatidis into the United Kingdom in live amphibians. Diseases of Aquatic Organisms 98, 95-112.

Price, S.J., Garner, T.W.J., Nichols, R.A., Balloux, F., Ayres, C., Mora-Cabello de Alba, A. et al. (2014). Collapse of amphibian communities due to an introduced ranavirus. Current Biology 24, 25862591.

Sabino-Pinto, J., Veith, M., Vences, M. \& Steinfartz, S. (2018). Asymptomatic infection of the fungal pathogen Batrachochytrium salamandrivorans in captivity. Scientific Reports 8, 11767.

Schloegel, L.M., Hero, J-M., Berger, L., Speare, R., McDonald, K. \& Daszak, P. (2006). The decline of the sharp-snouted day frog (Taudactylus acutirostris): The first documented case of extinction by infection in a free-ranging wildlife species? EcoHealth 3, 35-40.

Schloegel, L.M., Daszak, P., Cunningham, A.A., Speare, R. \& Hill, B. (2010). Two amphibian diseases, chytridiomycosis and ranaviral disease, now globally notifiable: an assessment by the O.I.E. ad hoc amphibian working group. Diseases of Aquatic Organisms 92, 101-108.
Skerratt, L.F., Berger, L., Speare, R., Cashins, S., McDonald, K.R., Phillott, A.D., et al. (2007). Spread of chytridiomycosis has caused the rapid global decline and extinction of frogs. EcoHealth 4, 125134.

Soto-Azat, C., Valenzuela-Sánchez, A., Clarke, B.T., Busse, K., Ortiz, J.C., Barrientos, C. et al. (2013). Is chytridiomycosis driving Darwin's frogs to extinction? PLOS ONE 8, e79862.

Spitzen-van der Sluijs, A., Martel, A., Asselberghs, J., Bales, E.K., Beukema, W., Bletz, M. C. et al. (2016). Expanding distribution of lethal amphibian fungus Batrachochytrium salamandrivorans in Europe. Emerging Infectious Diseases 22, 12861288.

Stegen, G., Pasmans, F., Schmidt, B.R., Rouffaer, L.O., Van Praet, S., Schaub, M. et al. (2017). Drivers of salamander extirpation mediated by Batrachochytrium salamandrivorans. Nature 544, 353-356.

Sumption, K.J. \& Flowerdew, J.R. (1985). The ecological effects of the decline in rabbits (Oryctolagus cuniculus L.) due to myxomatosis. Mammal Review 15, 151-186.

Tapley, B., Michaels, C.J., Gumbs, R., Böhm, M., Luedtke, J., Pearce-Kelly, P. et al. (2018). The disparity between species description and conservation assessment: A case study in taxa with high rates of species discovery. Biological Conservation 220, 209-214.

Teacher, A.G.F., Cunningham, A.A. \& Garner, T.W.J. (2010). The impact of ranavirus infection on wild common frog populations in the UK. Animal Conservation. 13, 514-522

Valenzuela-Sánchez, A., Schmidt, B.R., Uribe-Rivera, D., Costas, F., Cunningham, A.A. \& Soto-Azat, C. (2017). Cryptic disease-induced mortality may cause host extinction in an apparently-stable host-parasite system. Proceedings of the Royal Society B 284, 20171176.

Valenzuela-Sánchez, A., O'Hanlon, S.J., AlvaradoRybak, M., Uribe-Rivera, D., Cunningham, A.A., Fisher, M.C. et al. (2018). Genomic epidemiology of the emerging pathogen Batrachochytrium dendrobatidis from native and invasive amphibian species in Chile. Transboundary and Emerging Diseases 65, 309-314.

Voyles, J., Rosenblum, E.B. \& Berger, L. (2010). Interactions between Batrachochytrium dendrobatidis and its amphibian hosts: a review of pathogenesis and immunity. Microbes and Infection 13, 25-32.

Voyles, J., Young, S., Berger, L., Campbell, C., Voyles, W.F., Dinudom, A. et al. (2009). Pathogenesis of chytridiomycosis, a cause of catastrophic amphibian declines. Science 326, 582-585

Wolf, K., Bullock, G.L., Dunbar, C.E. \& Quimby, M.C. (1968). Tadpole edema virus: A viscerotropic pathogen for anuran amphibians. The Journal of Infectious Diseases 118, 253-262.

Wombwell, E.L., Garner, T.W.J., Cunningham, A.A., Quest, R., Pritchard, S., Rowcliffe, J. M. et al. 
(2016). Detection of Batrachochytrium dendrobatidis in amphibians imported into the UK for the pet trade. EcoHealth 13, 456-466.

Yuan, Z., Martel, A., Wu, J., Van Praet, S., Canessa, S. \& Pasmans, F. (2018). Widespread occurrence of an emerging fungal pathogen in heavily traded Chinese urodelan species. Conservation Letters e12436. 